\title{
Colposcopy in evaluation of suspected cervical cancer: a prospective, observational study
}

\author{
Ashwini Sudhir Desai, Shruti Panchbudhe*
}

Department of Obstetrics and Gynecology, Seth G. S. Medical College, Mumbai, Maharashtra, India

Received: 16 June 2020

Accepted: 10 July 2020

\section{*Correspondence:}

Dr. Shruti Panchbudhe,

E-mail: shrutipanchbudhe@gmail.com

Copyright: (C) the author(s), publisher and licensee Medip Academy. This is an open-access article distributed under the terms of the Creative Commons Attribution Non-Commercial License, which permits unrestricted non-commercial use, distribution, and reproduction in any medium, provided the original work is properly cited.

\begin{abstract}
Background: Cervical cancer is the fourth most frequent cancer in women according to World Health Organization. In India the incidence is approximately 1 in 53 compared with 1 in 100 women in more developed regions of the world. Cervical cancer is eminently preventable by early detection using various screening tests like Pap smear, colposcopy, HPV testing. In this study we aim to evaluate the use of colposcopy in early detection of cervical cancer and also assess risk factors for the same. Primary objective was to study the correlation between colposcopic findings and histopathological analysis with a secondary objective to assess risk factors for development of cervical neoplasia. Methods: The study was carried over a period of 2 years (October 2016 to October 2018) with a sample size of 60 in the department of obstetrics and gynecology at tertiary care centre. Participants who fit the inclusion criteria were included in the study after taking a written and informed consent. The colposcopy findings were correlated with the histopathological findings of the cervical biopsy that was undertaken.

Results: Colposcopy impression had sensitivity of $93.8 \%$ in predicting the histopathology, specificity was $77.3 \%$, positive predictive value was $60 \%$, negative predictive value was $9 \%$ and the diagnostic accuracy was $81.7 \%$. On analyzing the risk factors, it was found that the odds of malignant histopathology were 0.55 times decreasing with each unit increase in age (at first intercourse) ( $p$ value $<0.05$ ).

Conclusions: Colposcopy gives immediate and accurate results and its value as a diagnostic test is undisputable. The sensitivity of colposcopy is high and hence in high risk population or remote places where women do not turn for regular screening tests, colposcopy can be used primarily as the screening test.
\end{abstract}

Keywords: Colposcopy, Human papillomavirus testing, Pap smear, Sensitivity, Specificity

\section{INTRODUCTION}

Cervical cancer is the fourth most frequent cancer in women according to World Health Organization. Cervical cancer is a public health problem in developing countries like India as one-quarter of the worldwide cases of cervical cancer are seen in India. ${ }^{1,2}$ In India the incidence is approximately 1 in 53 compared with 1 in 100 women in more developed regions of the world. Cervical cancer is eminently preventable. ${ }^{2}$ Technologies to prevent cervical cancer are;
- Two prophylactic vaccines with high efficacy against HPV types 16 and 18, which cause $70 \%$ of cervical cancer cases globally and a nonavalent vaccine against five additional oncogenic HPV types that together with HPV-16, 18 cause up to $90 \%$ of cases

- Sensitive screening tests that detect oncogenic HPV infections and precancerous lesions

- $\quad$ Effective treatment of precancer stage. ${ }^{3}$

The ACOG recommends that every woman in the age group of 21-65 years has to undergo a screening for 
cervical cancer and is the optimal way for early detection. The various screening tests available for cervical cancer screening are Pap smear, visual inspection with acetic acid and Lugols iodine, HPV testing and colposcopy.

\section{Colposcopy}

Hans Hinselmann, a German physician developed the Colposcope along with Eduard. Colposcopy is a diagnostic as well as a screening technique used to detect cervical cancer4. It basically functions as a microscope with light source to magnify the view of the cervix, vagina, and vulvar surface. Higher magnification of $8 x$ to $25 \mathrm{x}$ is utilized to evaluate the vagina and cervix. Presence of atypical vascular patterns is characteristic of precancerous or cancerous lesions and high magnification along with green filter is often used to identify such vascular patterns. Application of acetic acid solution and iodine solution further helps in identifying the abnormal tissue and thus help in taking biopsy from appropriate site.

\section{METHODS}

\section{Study site}

This study was conducted in the department of obstetrics and gynecology at our tertiary care hospital. A total 60 patients. All the eligible subjects were recruited into the study consecutively by convenient sampling till the sample size is reached. The data collection for the study was done from October 2016 to October 2018.

\section{Inclusion criteria}

Women aged above 18 years undergoing colposcopy with cervical biopsy for any indication such as

- Abnormal pap smears

- Visible or palpable abnormality of cervix

- HPV infection detected on screening.

\section{Exclusion criteria}

- Women not consenting to be a part of the study

- Pregnant women

- Active cervico vaginal or pelvic infections.

Study was approved by institutional human ethics committee. Informed written consent was obtained from all the study participants.

A complete and detailed history was taken prior to the examination.

\section{Steps of examination}

- Patient in lithotomy position under local anaesthesia.
- First cervix is examined in low power and then moving to high power

- Green filter applied to look for abnormal vascular pattern

- Entire transformation zone seen to declare the colposcopy as satisfactory

- Acetic acid applied and acetowhite areas noted

- Schiller's iodine applied and iodine negative areas noted

- Cervical biopsy taken from acetowhite and iodine negative areas, atypical vessels if any also included in biopsy.

Colposcopy findings were noted and analysed. Clinical impression using Reids colposcopic index was noted.

\section{REID colposcopic index}

- $0-2=$ HPV OR CIN1

- 3-5= CIN I OR CIN II

- $6-8=$ CIN II OR CIN III

At colposcopy, the cases will be categorized into -

- Normal: squamous epithelium, columnar epithelium, transformation zone

- $\quad$ CIN I, II, III

- Invasive cancer

- Unsatisfactory - cervix not visible or squamocolumnar junction not visualized

- Miscellaneous - atrophy, keratosis, condyloma, polyp

Histopathological report of cervical biopsy noted and they were grouped into

- Normal

- Inflammation

- Metaplasia

- CIN I

- $\mathrm{CIN}$ II/III

- Invasive cancer

- Any other.

\section{Statistical analysis}

Colposcopy impression, histopathology were primary outcome variables. Descriptive analysis was carried out by mean and standard deviation for quantitative variables, frequency and proportion for categorical variables. Data was also represented using appropriate diagrams like bar diagram, pie diagram and box plots. Quantitative variables were assessed for compliance with normal distribution, by visual inspection of histograms and normality Q-Q plots. Statistical tests like Shapiro Wilk test and Kolmogrov Smirnov test p-values were also calculated. The association between explanatory variables and categorical outcomes was assessed by cross tabulation and comparison of percentages' value $<0.05$ 
was considered statistically significant. IBM SPSS version 22 was used for statistical analysis.

\section{RESULTS}

A total of 60 subjects were included in the final analysis.
Mean age of study population was 48.65 years with minimum 28 years and maximum 78 years (95\% CI 45.48- 51.82).

Among the study population only 14 (63.6\%) people were with post-menopausal bleeding.

Table 1: Descriptive analysis for age (in years) in study population $(\mathrm{N}=60)$.

\begin{tabular}{|lllllll|}
\hline Parameter & Mean \pm SD & Median & Min & Max & \multicolumn{2}{c|}{ 95\% CI for EXP (B) } \\
\hline Age (in years) & $48.65 \pm 12.25$ & 45.50 & 28.00 & 78.00 & 45.48 & 51.82 \\
\hline
\end{tabular}

Table 2: Descriptive analysis of postmenopausal bleeding in study population $(\mathrm{N}=60)$.

\begin{tabular}{|lll|}
\hline $\begin{array}{l}\text { Postmenopausal } \\
\text { bleeding }\end{array}$ & Frequency & Percentage \\
\hline Yes & 14 & $63.6 \%$ \\
\hline No & 8 & $36.4 \%$ \\
\hline
\end{tabular}

Among the study population 26 (43.33\%) had undergone Tubal ligation, $21(35.00 \%)$ used Barrier method of contraception, only $1(1.67 \%)$ used Hormonal method while $12(20.00 \%)$ did not use any contraception.

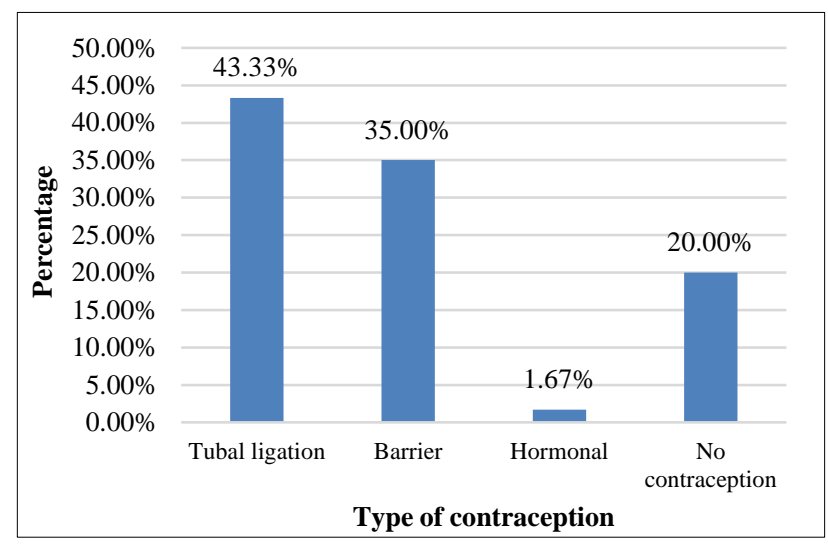

Figure 1: Type of contraception distribution in study population $(\mathrm{N}=60)$.

History of smoking or tobacco chewing was noted among $15(25.00 \%)$ people.

Among the study population only $3(5.00 \%)$ people were with History of sexually transmitted disease.
Table 3: Descriptive analysis of history of smoking or tobacco chewing in study population $(\mathrm{N}=60)$.

\begin{tabular}{|lll|}
\hline $\begin{array}{l}\text { History of smoking or } \\
\text { tobacco chewing }\end{array}$ & Frequency & Percentage \\
\hline Yes & 15 & $25.00 \%$ \\
\hline No & 45 & $75.00 \%$ \\
\hline
\end{tabular}

Table 4: Descriptive analysis of history of sexually transmitted disease in study population $(\mathrm{N}=60)$.

\begin{tabular}{|lll|}
\hline $\begin{array}{l}\text { History of sexually } \\
\text { transmitted disease }\end{array}$ & Frequency & Percentage \\
\hline Yes & 3 & $5.00 \%$ \\
\hline No & 57 & $95.00 \%$ \\
\hline
\end{tabular}

Mean age at first intercourse of study population was 17.98 years with minimum 14 years and maximum 24 years (95\% C.I 17.41- 18.55).

Among the study population only $1(1.67 \%)$ had history of genital warts.

The Pap smear details were 11 (18.83\%) were with inflammatory Pap smear, 47 (78.33\%) had atypical cells and $2(3.33 \%)$ had dysplastic cells on Pap smear.

The indications for colposcopy were grouped as follows: Pap smear abnormalities were the indication in 43 $(71.67 \%)$ while $12(20.00 \%)$ had visible or palpable abnormality of cervix and $4(6.67 \%)$ had atypical Pap smear as well as visible or palpable abnormality of cervix.

Table 5: Descriptive analysis for age at first intercourse in study population $(\mathrm{N}=60)$.

\begin{tabular}{|lllllll|}
\hline Parameter & Mean \pm SD & Median & Min & Max & \multicolumn{2}{c|}{ 95\% CI for EXP (B) } \\
\hline Age at first intercourse & $17.98 \pm 2.205$ & 18.00 & 14.00 & 24.00 & 17.41 & Upper \\
\hline
\end{tabular}




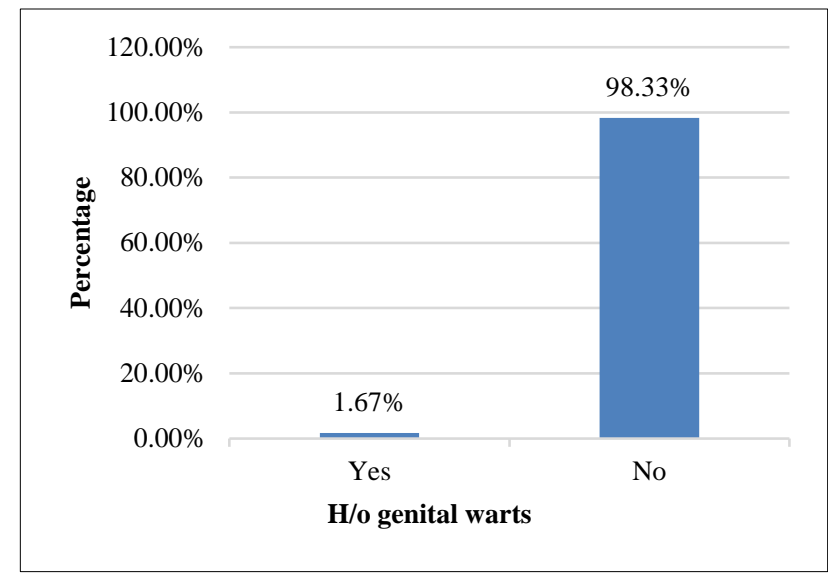

Figure 2: History of genital warts distribution in study population $(\mathrm{N}=60)$.

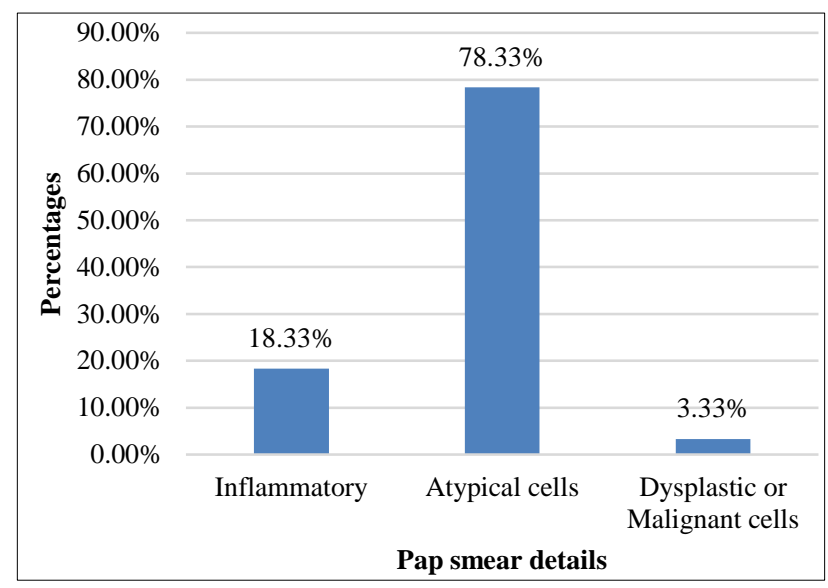

Figure 3: Pap smear details distribution in study population $(\mathrm{N}=60)$.

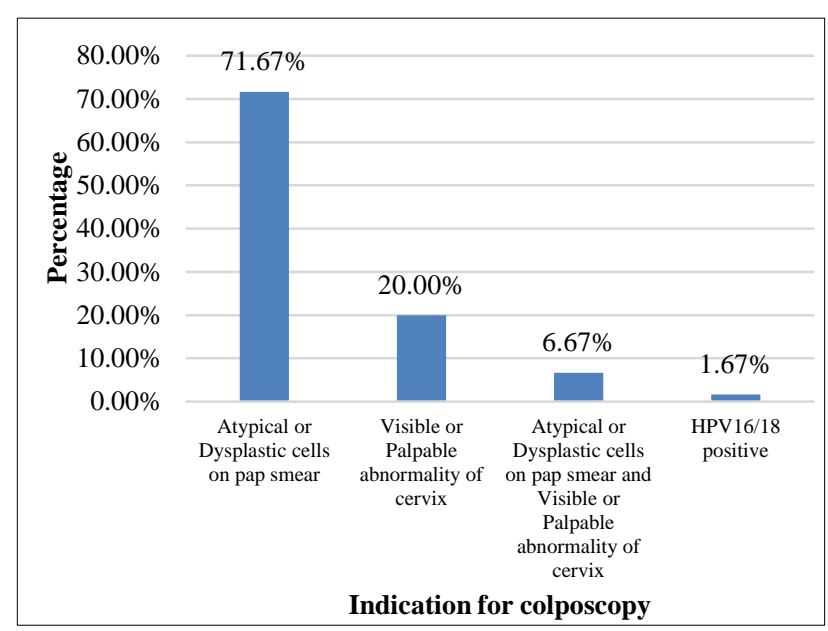

Figure 4: Indication for colposcopy distribution in study population $(\mathrm{N}=60)$.

On colposcopy, among the study population only 2 $(3.33 \%)$ were reported as polyp and $16(26.67 \%)$ cases of erosion while $17(28.33 \%)$ had atypical transformation zone. Punctations were seen in $28(46.67 \%)$ cases and 16
(26.67\%) had atypical vessels. Among the study population $5(8.33 \%)$ had ulcer and $38(63.33 \%)$ had Inflammatory changes while $8(13.33 \%)$ cases were colposcopically suspected as invasive carcinoma.

Table 6: Descriptive analysis of colposcopy findings in study population $(\mathrm{N}=60)$.

\begin{tabular}{|lll|}
\hline Colposcopy findings & Yes & No \\
\hline Polyp & $2(3.33 \%)$ & $58(96.67 \%)$ \\
\hline Erosion & $16(26.67 \%)$ & $44(73.33 \%)$ \\
\hline $\begin{array}{l}\text { Atypical transformation } \\
\text { zone }\end{array}$ & $17(28.33 \%)$ & $43(71.67 \%)$ \\
\hline Punctation & $28(46.67 \%)$ & $32(53.33 \%)$ \\
\hline Mosaic & $21(35.00 \%)$ & $39(65.00 \%)$ \\
\hline Atypical vessels & $16(26.67 \%)$ & $44(73.33 \%)$ \\
\hline Ulcer & $5(8.33 \%)$ & $55(91.67 \%)$ \\
\hline Inflammation & $38(63.33 \%)$ & $22(36.67 \%)$ \\
\hline $\begin{array}{l}\text { Colposcopically suspect } \\
\text { invasive carcinoma }\end{array}$ & $8(13.33 \%)$ & $52(86.67 \%)$ \\
\hline
\end{tabular}

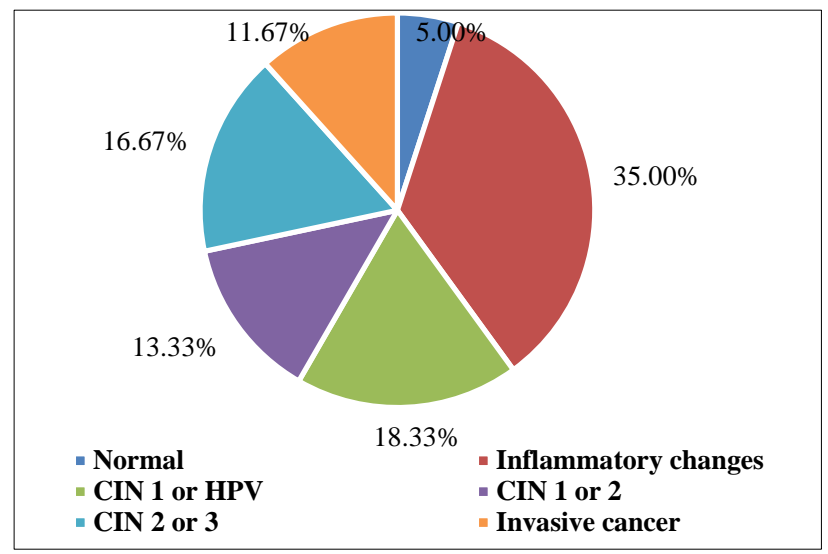

Figure 5: Impression distribution in study population $(\mathrm{N}=60)$.

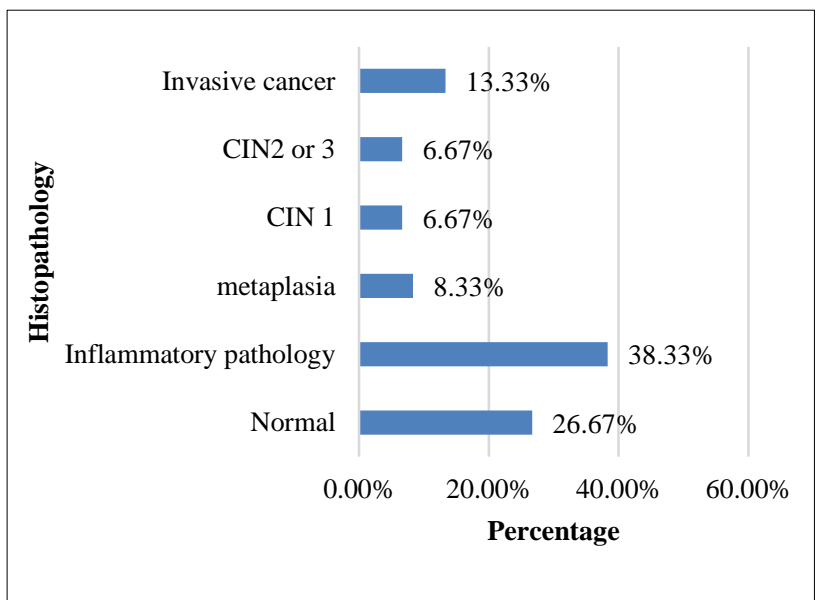

Figure 6: Histopathology distribution in study population $(\mathrm{N}=60)$.

As per the Reid's colposcopy index, 3 (5\%) were normal, $21(35 \%)$ inflammatory changes, $11(18.33 \%)$ were CIN 
1 or HPV, $8(13.33 \%)$ were CIN 1 or $2,10(16.67 \%)$ were CIN 2 or 3, 7 (11.67\%) were Invasive cancer.

On histopathology, $16(26.67 \%$ were normal, 23 $(38.33 \%)$ were inflammatory, $5(8.33 \%)$ had metaplasia, $4(6.67 \%)$ had CIN 1, $4(6.67 \%)$ had CIN2 or 3 and 8 $(13.33 \%)$ had Invasive cancer.
Among the malignant histopathology, 15 (93.8\%) were malignant impression and only $1(6.3 \%)$ were benign impression. Among the benign histopathology, only 10 $(22.7 \%)$ were malignant impression and $34(77.3 \%)$ were benign impression. The difference in the proportion of impressions between different histopathology was statistically significant ( $\mathrm{p}$ value $<0.001$ ).

Table 7: Comparison of histopathology between colposcopy impression $(\mathrm{N}=60)$.

\begin{tabular}{|lllllll|}
\hline Histopathology & $\begin{array}{l}\text { Impression } \\
\text { Normal } \\
(\mathbf{N = 3})\end{array}$ & $\begin{array}{l}\text { Inflammatory } \\
\text { changes } \\
(\mathbf{N = 2 1})\end{array}$ & $\begin{array}{l}\text { CIN 1 or } \\
\text { HPV } \\
(\mathbf{N = 1 1}\end{array}$ & $\begin{array}{l}\text { CIN 1 or 2 } \\
(\mathbf{N = 8})\end{array}$ & $\begin{array}{l}\text { CIN 2 or 3 } \\
(\mathbf{N = 1 0})\end{array}$ & $\begin{array}{l}\text { Invasive } \\
\text { cancer } \\
(\mathbf{N}=7)\end{array}$ \\
\hline Normal & $3(100 \%)$ & $9(42.85 \%)$ & $1(9.090 \%)$ & $3(37.5 \%)$ & $0(0 \%)$ & $0(0 \%)$ \\
\hline Inflammatory pathology & $0(0 \%)$ & $11(52.38 \%)$ & $10(90.90 \%)$ & $2(25 \%)$ & $0(0 \%)$ & $0(0 \%)$ \\
\hline metaplasia & $0(0 \%)$ & $0(0 \%)$ & $0(0 \%)$ & $3(37.5 \%)$ & $2(20 \%)$ & $0(0 \%)$ \\
\hline CIN 1 & $0(0 \%)$ & $0(0 \%)$ & $0(0 \%)$ & $0(0 \%)$ & $4(40 \%)$ & $0(0 \%)$ \\
\hline CIN2 or 3 & $0(0 \%)$ & $1(4.761 \%)$ & $0(0 \%)$ & $0(0 \%)$ & $3(30 \%)$ & $0(0 \%)$ \\
\hline Invasive cancer & $0(0 \%)$ & $0(0 \%)$ & $0(0 \%)$ & $0(0 \%)$ & $1(10 \%)$ & $7(100 \%)$ \\
\hline
\end{tabular}

Table 8: Comparison of histopathology between impression malignant and benign $(\mathrm{N}=60)$.

\begin{tabular}{|c|c|c|c|c|}
\hline \multirow{2}{*}{ Impression } & \multicolumn{2}{|l|}{ Histopathology } & \multirow{2}{*}{ Chi square } & \multirow{2}{*}{ p value } \\
\hline & Malignant $(\mathrm{N}=16)$ & Benign $(\mathrm{N}=44)$ & & \\
\hline Malignant & $15(93.8 \%)$ & $10(22.7 \%)$ & \multirow{2}{*}{24.351} & \multirow{2}{*}{$<0.001$} \\
\hline Benign & $1(6.3 \%)$ & $34(77.3 \%)$ & & \\
\hline
\end{tabular}

Table 9: Predictive validity of colposcopy impression as compared to histopathology $(\mathrm{N}=60)$.

\begin{tabular}{|llll|}
\hline Parameter & Value & $\begin{array}{l}\text { 95\% CI } \\
\text { Lower }\end{array}$ & Upper \\
\hline Sensitivity & $93.8 \%$ & $81.98 \%$ & $100.0 \%$ \\
\hline Specificity & $77.3 \%$ & $64.92 \%$ & $89.7 \%$ \\
\hline False positive rate & $22.7 \%$ & $10.32 \%$ & $35.1 \%$ \\
\hline False negative rate & $6.3 \%$ & $1.00 \%$ & $18.2 \%$ \\
\hline Positive predictive value & $60.0 \%$ & $40.80 \%$ & $79.2 \%$ \\
\hline Negative predictive value & $97.1 \%$ & $91.54 \%$ & $100.0 \%$ \\
\hline Diagnostic accuracy & $81.7 \%$ & $71.88 \%$ & $91.5 \%$ \\
\hline
\end{tabular}

Table 10: Univariate analysis of risk factors associated with histopathology findings.

\begin{tabular}{|c|c|c|c|c|}
\hline \multirow[t]{2}{*}{ Parameter } & \multirow{2}{*}{$\begin{array}{l}\text { Un-adjusted } \\
\text { odds ratio }\end{array}$} & \multicolumn{2}{|c|}{$\begin{array}{l}95 \% \text { CI for } \\
\text { unadjusted odds ratio }\end{array}$} & \multirow[t]{2}{*}{ p value } \\
\hline & & Lower & Upper & \\
\hline Age & 1.04 & 0.99 & 1.09 & 0.11 \\
\hline Age (at first intercourse) & 0.55 & 0.37 & 0.83 & 0.004 \\
\hline Post-menopausal bleeding (baseline-no) & 0.9 & 0.15 & 5.26 & 0.91 \\
\hline \multicolumn{5}{|l|}{ Type of contraception } \\
\hline Tubal ligation & 0.300 & 0.070 & 1.283 & 0.104 \\
\hline Barrier & 0.235 & 0.049 & 1.132 & 0.071 \\
\hline Hormonal & 0.000 & 0.000 & & 1.000 \\
\hline \multicolumn{5}{|l|}{ No contraception (baseline) } \\
\hline History of smoking or tobacco chewing (baseline-no) & 3.5 & 1.003 & 12.22 & 0.05 \\
\hline History of sexually transmitted disease (baseline-no) & 6.14 & 0.52 & 72.99 & 0.15 \\
\hline
\end{tabular}


The following results were seen while correlating colposcopy and histopathological findings: Among the normal impression all $3(100 \%)$ were normal on histopathology as well. Among the colposcopy impression of inflammation, $9(42.85 \%)$ were normal and $11(52.38 \%)$ were inflammatory pathology while 1 (4.761\%) was CIN2 or 3 on histopathology.

Among CIN1 or HPV, $1(9.09 \%)$ was normal and 10 $(90.90 \%)$ were inflammatory pathology on histopathology. Among CIN 1or 2 normal and metaplasia in histopathology as 3 (37.55) in each and only 2 (25\%) were with inflammatory pathology. Among the CIN 2or 3, $2(20 \%)$ were metaplasia, 4 (40\%) were CIN1, 3 (30\%) were CIN 2 or 3 and $1(10 \%)$ was with invasive cancer on histopathology. Among invasive cancer impression people all 7 (100\%) were invasive cancer on histopathology.

Colposcopy impression had sensitivity of $93.8 \%$ (95\% CI $81.98 \%$ to $100 \%$ ) in predicting the histopathology. Specificity was $77.3 \%$ (95\% CI $64.92 \%$ to $89.7 \%$ ), false positive rate was $22.7 \%$ (95\% CI $10.32 \%$ to $35.1 \%$ ), false negative rate was $6.3 \%$ (95\% CI $1.0 \%$ to $18.2 \%$ ), Positive predictive value was $60 \%$ (95\% CI $40.80 \%$ to $79.2 \%$ ), negative predictive value was $9 \%$. 1 (95\% CI $91.54 \%$ to $100 \%)$ and the diagnostic accuracy was $81.7 \%$ (95\% CI $71.88 \%$ to $91.5 \%$ ). On analysing the risk factors, it was found that the odds of malignant histopathology were 0.55 times decreasing with each unit increase in age (at first intercourse) (95\% CI 0.37-0.83) (p value<0.05).

\section{DISCUSSION}

\section{Risk factors}

When all the factors were used in regression analysis, only one factor was found significant. The odds of malignant histopathology were 0.55 times decreasing with each unit increase in age (at first intercourse) $(95 \%$ CI 0.37-0.83) ( $\mathrm{p}$ value <0.05). Lack of use of barrier contraception could be possible cause.

\section{Histopathological findings}

In the current study, the histopathological report was normal in $16(26.67 \%)$ participants. 23 (38.33\%) had Inflammation, $5(8.33 \%)$ had metaplasia, $4(6.67 \%)$ had CIN 1, $4(6.67 \%)$ with CIN2 or 3 and $8(13.33 \%)$ had invasive cancer. This was found to be in accordance with various studies like those undertaken by Boicea A, et al, Satyanarayan L et al, Scouza CA et al respectively. ${ }^{5-7}$

\section{Colposcopy findings}

In the current study, the colposcopy impressions were 3 $(5 \%)$ were normal, $21(35 \%)$ had inflammatory changes, $11(18.33 \%)$ had CIN 1 or HPV, $8(13.33 \%)$ had CIN 1 or $2,10(16.67 \%)$ had CIN 2 or $3,7(11.67 \%)$ were invasive cancer. This was again in accordance with Boicea A et al and Satyanarayana L et al.,

Table 11: Comparison of histopathological findings with other studies.

\begin{tabular}{|c|c|c|c|}
\hline Current study & Boicea A et al & Satyanarayana $L$ et al & Souza CA et al \\
\hline $\begin{array}{l}\text { Normal: } 16(26.67 \%) \\
\text { inflammation: } 23(38.33 \%) \\
\text { metaplasia: } 5(8.33 \%) \text { CIN } \\
\text { 1: } 4(6.67 \%) \text { CIN2 or } 3: 4 \\
(6.67 \%), \text { invasive cancer: } 8 \\
(13.33 \%)\end{array}$ & $\begin{array}{l}\text { Normal: } 4 \text { (1.6\%) CIN I: } \\
26(10.6 \%) \text {, CIN II: } 55 \\
(22.4 \%) \text {, CIN III: } 138 \\
(56.3 \%) \text { micro-invasive } \\
\text { carcinoma: } 15(6.1 \%)\end{array}$ & $\begin{array}{l}\text { Normal/inflammation: } 1,066 \\
(64 \%) \text { CIN 1: } 438(26.6 \%) \\
\text { CIN 2-3: } 134(8.15 \%) \\
\text { invasive cancer: } 6(0.3 \%)\end{array}$ & $\begin{array}{l}\text { No neoplasia: } 22 \text { (27.5) } \\
\text { CIN 1: } 43 \text { (53.8) CIN 2: } \\
11 \text { (13.8) CIN 3: } 3 \text { (3.8) } \\
\text { Malignant neoplasia: } 1 \\
\text { (1.3). }\end{array}$ \\
\hline
\end{tabular}

Table 12: Comparison between colposcopy findings in present study and other studies.

\begin{tabular}{|lll|}
\hline Current study & Boicea A et al & Satyanarayana L et al \\
\hline Normal: $3(5 \%)$ were inflammatory changes: & $28(11.4 \%)$ cases were CIN I, 50 & Normal/Inflammation: \\
$21(35 \%)$ CIN 1 or HPV: 11 $(18.33 \%)$, CIN & $(20.4 \%)$ cases were CIN II, 150 & $2,720(97.1 \%)$ CIN 1: \\
$\begin{array}{l}\text { 1 or 2: } 8(13.33 \%) \text { CIN 2 or 3: } 10(16.67 \%), \\
\text { invasive cancer: } 7(11.67 \%)\end{array}$ & $\begin{array}{l}\text { cases were micro-invasive carcinoma } \\
\text { and four }(1.6 \%) \text { cases were CIS. }\end{array}$ & $\begin{array}{l}71(2.5 \%) \text { CIN 2-3: } 9(0.4 \%) \\
\text { invasive cancer: } 1\end{array}$ \\
\hline
\end{tabular}

\section{Agreement}

In the current study, in the normal colposcopy impression all $3(100 \%)$ were normal in histopathology, among the inflammatory impression $9(42.85 \%)$ were normal and 11 $(52.38 \%)$ were inflammatory pathology and 1 (4.761\%) was CIN2 or 3 in histopathology. Among CIN1 or HPV 1
(9.09\%) was normal and $10(90.90 \%)$ were inflammatory pathology in histopathology. Among CIN 1or 2 normal and metaplasia in histopathology as 3 (37.55) in each and only $2(25 \%)$ were with inflammatory pathology. Among the CIN 2 or 3, $2(20 \%)$ were metaplasia, $4(40 \%)$ were CIN1, $3(30 \%)$ were CIN 2 or 3 and $1(10 \%)$ was with invasive cancer in histopathology. Among invasive 
cancer impression people all $7(100 \%)$ were invasive cancer in histopathology.

Table 13: Diagnostic accuracy of colposcopy across various studies.

\begin{tabular}{|ll|}
\hline Studies & Value in percentage \\
\hline Massad LS et al & $86.0 \%$ \\
\hline Savitha T et al & $85.0 \%$ \\
\hline Arora RS et al & $87.0 \%$ \\
\hline Present study & $81.7 \%$ \\
\hline
\end{tabular}

\section{Diagnostic accuracy}

In the current study the diagnostic accuracy was $81.7 \%$ which was lesser compared to the studies done by Massad LS et al, Savitha T et al and Arora RS et al was $86 \%, 85 \%$ and $87 \%$ respectively. ${ }^{9-11}$

\section{CONCLUSION}

Despite availability of various screening methods in India utilization of the services is very poor. The high incidence and prevalence of cervical cancer in India and Southeast Asian countries is due to poor to moderate living standards, a high prevalence of HPV (more than $10 \%$ in women aged more than 30 years) and due to lack of screening. As cervical cancer has a precancerous stage and there is a lag period of 10-20 years to develop into invasive cancer, screening procedures become imperative.

Colposcopy gives immediate and accurate results and its value as a diagnostic test is undisputable. The sensitivity of colposcopy is high and hence in high risk population or remote places where women do not turn for regular screening tests, colposcopy can be used primarily as the screening test.

Funding: No funding sources

Conflict of interest: None declared

Ethical approval: The study was approved by the Institutional Ethics Committee

\section{REFERENCES}

1. DeSantis CE, Bray F, Ferlay J, Lortet-Tieulent J, Anderson $\mathrm{BO}$, Jemal A. International variation in female breast cancer incidence and mortality rates. Cancer Epidemiol Biomark Prevent. 2015;24(10):1495-506.

2. Ferlay J, Soerjomataram I, Dikshit R, Eser S, Mathers C, Rebelo M, et al. Cancer incidence and mortality worldwide: Sources, methods and major patterns in GLOBOCAN 2012. Int $\mathbf{J}$ Cancer. 2015;136(5):E359-86.

3. Li N, Franceschi S, Howell-Jones R, Snijders PJF, Clifford GM. Human papillomavirus type distribution in 30,848 invasive cervical cancers worldwide: Variation by geographical region, histological type and year of publication. Int $\mathbf{J}$ Cancer. 2011;128(4):927-35.

4. Chase DM, Kalouyan M, DiSaia PJ. Colposcopy to evaluate abnormal cervical cytology in 2008. In Am J Obstet Gynecol. 2009;200(5):472-80.

5. Boicea A, Pătraşcu A, Surlin V, Iliescu D, Schenker M, Chiuţu L. Correlations between colposcopy and histologic results from colposcopically directed biopsy in cervical precancerous lesions. Romanian J Morphol Embryol Revue Roumaine de Morphologie et Embryologie. 2012;53(3 Suppl):735-41.

6. Satyanarayana L, Asthana S, Bhambani S, Sodhani P, Gupta S. A comparative study of cervical cancer screening methods in a rural community setting of North India. Indian J Cancer. 2014;51(2):124-8.

7. de Souza CA, Discacciati MG, d'Otavianno MG, Bergo SM, Traue M, de Angelo Andrade LA, et al. Underdiagnosis of cervical intraepithelial neoplasia (CIN) 2 or Worse Lesion in Women with a Previous Colposcopy-Guided Biopsy Showing CIN 1 Subdiagnóstico de neoplasia intraepitelial cervical (NIC) 2 ou lesão mais grave em mulheres com biópsia. Rev Bras Ginecol Obstet. 2017 Mar;39(3):123-7.

8. Pimple SA, Amin G, Goswami S, Shastri SS. Evaluation of colposcopy vs cytology as secondary test to triage women found positive on visual inspection test. Indian J Cancer. 2010;47(3):308-13.

9. Massad LS, Weber KM, Wilson TE, Goderre JL, Hessol NA, Henry D, et al. Correlating knowledge of cervical cancer prevention and human papillomavirus with compliance after colposcopy referral. J Lower Genital Tract Dis. 2012;16(2):98105.

10. Savitha TS, Waghmare S. A comparison of pap smear, colposcopy and colposcopy directed biopsy in evaluation of unhealthy cervix. J Evol Med Dent Sci. 2015;4(21):3639-47.

11. Arora RS, Patel SM, Poddar P. A study of cytology and colposcopy in VIA (visual inspection of cervix with 5\% acetic acid) positive women. Int $\mathbf{J}$ Reprod Contracept Obstet Gynecol. 2018;7(2):571.

Cite this article as: Desai AS, Panchbudhe S.

Colposcopy in evaluation of suspected cervical cancer: a prospective, observational study. Int J Reprod Contracept Obstet Gynecol 2020;9:3432-8. 